\title{
Central Abscess of the Calcaneal Tendon: Report of the 1st case and Literature Review
}

Badarou Chaibou1*, Mohamed Abdoulwahab ${ }^{2}$, Mahamadou Habibou ${ }^{2}$, George Saad ${ }^{3}$, Mohammed Zaaf ${ }^{3}$, Abdelmajid Elmrini ${ }^{1}$

${ }^{1}$ University hospital center of Fès, Morocco

${ }^{2}$ General referral hospital of Niamey, Niger

${ }^{3}$ South Essonne hospital center, France

Submission: February 03, 2020; Published: February 13, 2020

*Corresponding author: Badarou Chaibou, University hospital center of Fès, Morocco

\begin{abstract}
The calcaneal tendon is the frequent site of variable tendinopathies. Abscesses at this site are exceptional. We report the case of a central abscess of the calcaneal tendon in a 37-year-old woman, chronic smoking. The diagnosis was made by imagery. Management was surgical. Samples were taken for cytobacteriological and histological studies. Appropriate antibiotic therapy was administered with complete remission without recurrence at the last follow-up of 6 months. An ultrasound control objectified a continuous tendon with filling of the loss of substance, without collection.
\end{abstract}

Keywords: Abscess; Calcaneal tendon

\section{Introduction}

The calcaneal tendon is the largest of the tendons (average of $0.5 \mathrm{~cm}$ in diameter). Being the termination of the sural triceps, it participates in plantar foot flexion and propulsion during the walking cycle. This tendon is the site of very frequent pathologies grouped under the term of tendinopathy of the calcaneal tendon

[1]. These are most often inflammatory or degenerative lesions. Infections with abscesses are almost never encountered there. The most incriminated germs in abscess are staphylococcus aureus, streptococcus and anaerobes in 70\% of cases [2]. Others germs like Escherichia coli has been isolated [2]. We report the first case in the literature of a central abscess of the calcaneal tendon.
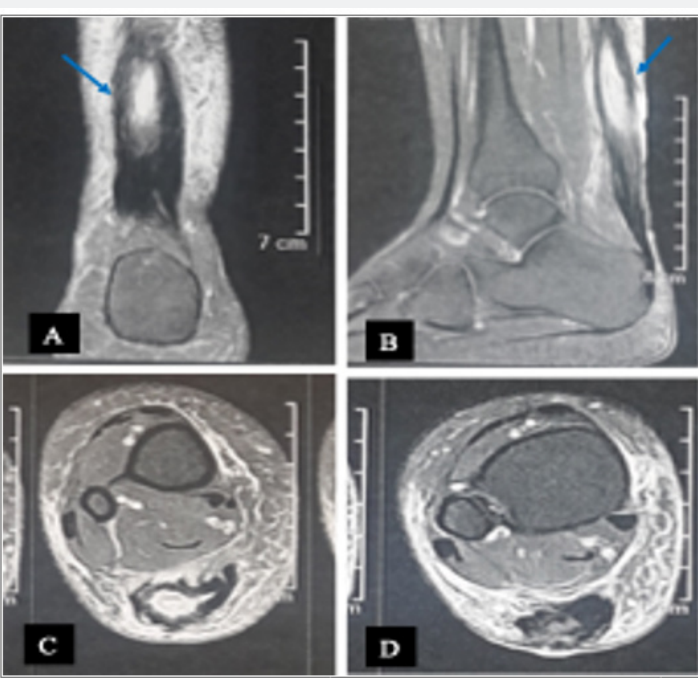

Figure 1: MRI of the right leg and ankle. Collection (blue arrows) in intense hypersignal (A, B, C) with breaking of the fibers in the $1 / 3$ middle of the calcaneal tendon and an infiltration of the soft parts $(D)$. 


\section{Case Report}

It was a 37-year-old woman, with previous notion of minimal pain at the right calcaneal tendon in the past 6 weeks after treatment with ciprofloxacin (urinary tract infection), smoking at the rate of 5 packs-year. She presented moderate pains on the posterior face of the distal $1 / 3$ of the right leg with minimal swelling evolving for 15 days. The calf was flexible. Plantar flexion was retained. The distal pulses were present and symmetrical. She was non-pyretic. Without any other sign elsewhere. The rest of the clinical examination was unremarkable. Standard radiography showed a marked area of opacity opposite the calcaneal tendon. Magnetic resonance imaging objectified a very swollen calcaneal tendon with an intense hyper signal witnessing a collection within the tendon and an interruption of the fibers at $1 / 3$ average (Figure 1). It is associated with an infiltration of the soft tissue. The leukocytes were $=9740 / \mathrm{mm} 3$ and the C-reactive protein $(\mathrm{CRP})=28 \mathrm{mg} / \mathrm{L}$. the patient had received surgical drainage by medial par-calcaneal approach (Figure 2). We realize samples for cytobacteriological and histological study. The result was in favor of infection with gram-negative bacilli (Escherichia coli, ceftriaxone-sensitive). The patient had received $2 \mathrm{~g}$ /day for 2 weeks. Clinical and biological monitoring were established. Functional rehabilitation was realized after skin scarring. The evolution was satisfactory without recurrence or tendon rupture at the last follow-up of 6 months. An ultrasound control objectified a continuous tendon with filling of the loss of substance, without collection.
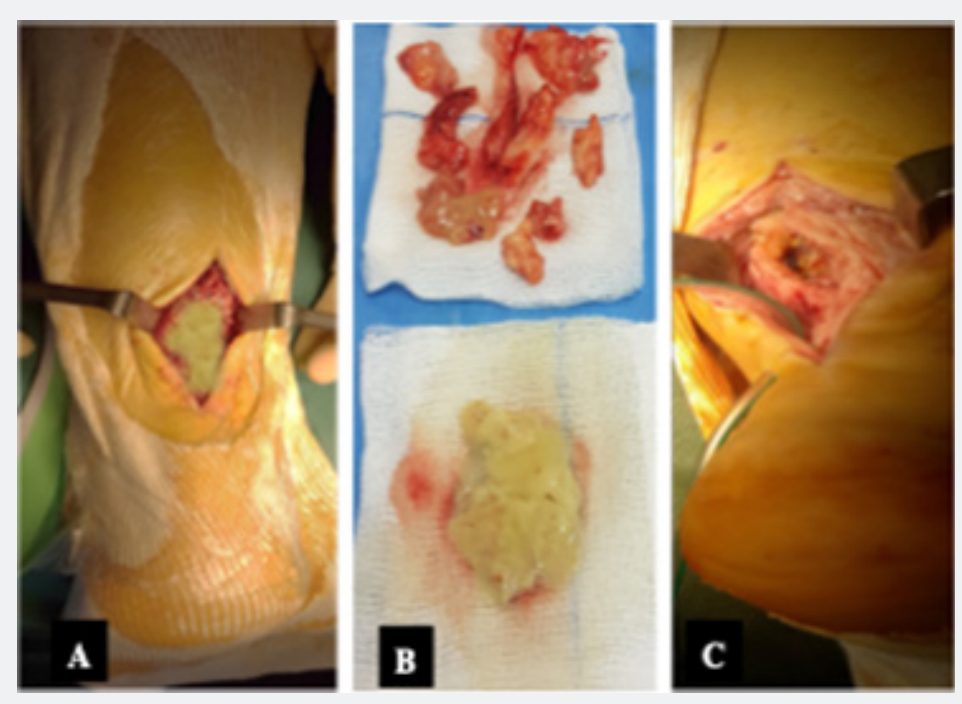

Figure 2: Intraoperative aspect. (A): gush of franc pus, yellowish on opening; (B): samples of pus and soft tissue; (C): the vacuum left, corresponding to the loss of tendon substance.

\section{Discussion}

The term tendinopathy refers to a clinical syndrome that combines pain, swelling and reduced functional capacity [1]. It is preferred to the term like tendinitis or tendons which respectively designate an inflammatory process for one and degenerative for the other. However, it does not necessarily refer to the abscessed collections since never reported in the literature. The most incriminated germs in abscess are staphylococcus aureus, streptococcus and anaerobes in $70 \%$ of cases [2]. Other germs like Escherichia coli has been isolated following a bacteremia with urinary or digestive starting point [2]. other agents isolated pathogens in abscesses have been reported in the literature: Klebsiella, Salmonella typhi, Acinetobacter, Mycobacterium tuberculosis, Pseudomonas, Eikenella corrodens, Clostridium, Fusobacterium mortiferum, Pneumocystis carnii, Haemophilus $[3,4]$ as well as fungal agents such as: Candida albicans, and aspergillosis $[3,5]$. These species have been identified in patients with immunosuppression [6,7]. But no localization at the level of the tendon fibers. Through this case we want to show that although exceptional, the central abscess of the calcaneal tendon exists. What would be the mechanism? we suggest two hypotheses. The first, the most likely: it was a patient who was received a quinolone, that molecule caused a partial rupture of the median fibers at the level of the middle $1 / 3$ of the calcaneal tendon with collection of a hematoma which had secondarily abscessed. In fact, the risk of tendon rupture secondary to the use of quinolones has been reported. And the rupture concerns the Achilles tendon in $90 \%[8,9]$.

The second hypothesis: hematogenous dissemination of his urinary tract infection with secondary localization in the calcaneal tendon weakened by quinolones. We can also evoke a hypothesis related to chronic smoking in this patient. The first step in its management is drainage to prevent complications such as complete rupture of the calcaneal tendon, fuse of the abscess, 
extension of necrosis with loss of tendon substance. It is a fragile tendon that would require rest to promote healing with regular check-ups.

\section{Conclusion}

The diagnosis of abscess is easy. Management follows the same rules as the abscesses commonly encountered. However, the development of an abscess at this level can be serious with the possibility of dissemination, rupture of the tendon and loss of substance by necrosis. Hence the interest in adequate care and monitoring of patients.

\section{Ethics Approval and consent to participate}

We obtained the informed consent from the patient to report this case.

\section{Human and Animal Rights}

No animals/humans were used for studies that are base of this research.

\section{Acknowledgement}

All authors contributed to proofreading and editing the manuscript before submission.

\section{Conflict of Interest}

Authors declare that they have no conflict of interest.

\section{References}

1. Van Dijk CN, van Sterkenburg MN, Wiegerinck JI, Karlsson J, Maffulli N, et al. (2011) Terminology for Achilles tendon related disorders. Knee Surg Sports Traumatol Arthrosc 19(5): 835-841.

2. Sicilia V, Mezitis S (2006) A case of acute suppurative thyroiditis complicated by thyrotoxicosis. J Endocrinol Invest 29(11): 997-1000.

3. Herndon MD, Christie DB, Ayoub MM, Duggan AD (2007) Thyroid abscess: case report and review of the literature. Am Surg 73(7): 725728.

4. Reuben F De Sousa, Amonkar Dilip, Correia Mervyn (2008) Thyroid Abscess with Cutaneous Fistula: Case Report and Review of the Literature. Thyroid Science 3(11): CR1-4.

5. Lisbona R, Lacourciere Y, Rosenthall L (1973) Aspergillomatous abscesses of the brain and thyroid. J Nucl Med 14(7): 541-542.

6. Basílio-De-Oliveira CA (2000) Infectious and neoplastic disorders of the thyroid in AIDS patients: an autopsy study. Braz J Infect Dis 4(2): 67-75.

7. Wang YC, Yeh TS, Lin JD (1997) Gram-negative thyroid abscess resulting from fine-needle aspiration in an immunosuppressed patient. Clin Infect Dis 25(3): 745-746.

8. Kirchgesner T, Larbi A, Omoumi P, Malghem J, Zamali N (2014) Druginduced tendinopathy: From physiology to clinical applications. Joint Bone Spine 81(6): 485-492.

9. Van der Linden PD, van Puijenbroek EP, Feenstra J, Veld BA, Sturkenboom MC, et al. (2001) Tendon disorders attributed to fluoroquinolones: A study on 42 spontaneous reports in the period 1988 to 1998. Arthritis Rheum 45(3): 235-239.

\section{Your next submission with Juniper Publishers will reach you the below assets}

- Quality Editorial service

- Swift Peer Review

- Reprints availability

- E-prints Service

- Manuscript Podcast for convenient understanding

- Global attainment for your research

- Manuscript accessibility in different formats ( Pdf, E-pub, Full Text, Audio)

- Unceasing customer service

Track the below URL for one-step submission https://juniperpublishers.com/online-submission.php 